P-ISSN $2580-7781$

E-ISSN 2615 - 3238

\title{
PENDIDIKAN DI ERA DIGITAL YANG MEREDUKSI NILAI BUDAYA
}

\section{EDUCATION IN A DIGITAL ERA WHICH REDUCES CULTURAL VALUE}

\author{
Annisa Dwi Hamdani \\ Program Studi Pendidikan Guru Sekolah Dasar, Kampus Daerah Cibiru, \\ Universitas Pendidikan Indonesia \\ Email: annisadwihamdani@upi.edu
}

\begin{abstract}
ABSTRAK
Penelitian ini bertujuan untuk memberikan gambaran mengenai pendidikan di era digital yang mereduksi nilai budaya. Metode penelitian yang dilakukan adalah penelitian deskriptif yang berdasarkan pada pendapat para ahli atau penelitian terdahulu dan mengumpulkan data-data dari beberapa jurnal ilmiah dan buku. Perkembangan teknologi terjadi begitu cepat dan membawa pengaruh yang signifikan pada kehidupan. Perkembangan teknologi dapat membawa dampak negatif juga dampak positif dalam kehidupan. Salah satu dampak negatif dari perkembangan teknologi adalah mereduksi nilai-nilai budaya, sehingga diperlukan penanaman nilai-nilai budaya Indonesia yang dilakukan melalui proses pembelajaran dan pendidikan. Selain melakukan penanaman nilai budaya pada masyarakat, diperlukan juga literasi teknologi bagi seluruh masyarakat agar dapat melakukan filterisasi informasi yang terkandung dalam teknologi. Kemudian diperlukan peran masyarakat dalam mengimplementasikan juga mempertahankan nilainilai budaya yang telah tertanam agar tidak mudah terkikis oleh isu-isu global. Karena pendidikan, kebudayaan, dan masyarakat merupakan suatu komponen yang terpadu dan tidak dapat dipisahkan baik di era digital ataupun di era sebelumnya.
\end{abstract}

Kata kunci: Pendidikan, Era digital, Nilai budaya.

\begin{abstract}
This study aims to provide an overview of education in the digital era which reduces cultural values. The research method used is descriptive research based on the opinion of experts or previous research and collects data from several scientific journals and books. Technological developments occur so fast and have a significant impact on life. Technological developments can have a negative impact as well as a positive impact on life. One of the negative impacts of technological development is reducing cultural values, so it is necessary to inculcate Indonesian cultural values through a process of learning and education. In addition to cultivating cultural values in society, technological literacy is also needed for the entire community so that they can filter the information contained in technology. Then it takes the role of the community in implementing and maintaining the cultural values that have been embedded so that global issues are not easily eroded. Because education, culture, and society are integrated and inseparable components both in the digital era and in the previous era.
\end{abstract}

Keywords: Education, Digital era, Culture value.

\section{PENDAHULUAN}

Perkembangan teknologi merupakan fenomena yang terjadi begitu cepat dan memberikan dampak yang cukup signifikan dalam kehidupan. Perkembangan teknologi ini dinilai dapat memberikan manfaat dan juga dapat dianggap 
P-ISSN $2580-7781$

E-ISSN 2615 - 3238

membawa pengaruh buruk atau dampak negatif bagi kehidupan. Dalam dunia pendidikan perkembangan teknologi berpengaruh dalam berbagai aspek. Oleh karena itu, dibutuhkan tenaga pendidikan dan kependidikan yang profesional dan terampil untuk dapat melahirkan pendidikan yang berkualitas di era digital ini.

Perkembangan teknologi ini sudah termasuk pada bagian kehidupan yang menjadikan manusia menjadi gemar dan terkungkung akan teknologi, sehingga teknologi dianggap tidak dapat dipisahkan dari kehidupan manusia (Herlambang, 2018). Sangat banyak dampak negatif dan dampak positif yang terdapat dalam perkembangan teknologi. Salah satu dampak negatif yang banyak ditemukan pada kalangan masyarakat akibat perkembangan teknologi adalah mereduksi nilai-nilai budaya.

Nilai-nilai budaya adalah suatu nilai yang telah disepakati dan tertanam pada suatu masyarakat tertentu yang biasanya berupa sebuah kebiasaan, kepercayaan, karakteristik, dan lainnya yang dapat menjadi acuan perilaku masyarakat tersebut. Mereduksi nilai-nilai budaya adalah suatu fenomena dari perkembangan teknologi yang menjadikan manusia mudah terpengaruh oleh berbagai isu global, sehingga nilai-nilai budaya lokal semakin berkurang atau terkikis (Herlambang, 2018).

Dunia pendidikan harus bisa menyesuaikan diri dan mengikuti perkembangan teknologi yang ada. Maka dalam menjalankan pendidikan berbasis digital ini diperlukan tenaga pendidik yang kompeten dan profesional. Pendidik harus bisa menyeimbangkan antara perkembangan teknologi dengan nilai-nilai budaya yang telah ada. Karena secara umum pendidikan merupakan suatu usaha yang terencana dan usaha sadar dalam mengaktualkan proses pembelajaran yang dapat membuat peserta didik aktif mengembangkan potensi dirinya agar memiliki nilai-nilai dan keterampilan yang diperlukan untuk dirinya dan juga masyarakat (Ngongo et al, 2019).

Kegiatan mewariskan budaya dari setiap generasi merupakan peran pendidikan sebagai proses transformasi budaya. Pendidikan dengan kebudayaan memiliki keterkaitan yang tidak dapat dipisahkan karena budaya dapat dilestarikan melalui proses pendidikan dan pendidikan berbasis budaya akan 
P-ISSN $2580-7781$

E-ISSN 2615 - 3238

membantu generasi agar memiliki nilai-nilai budaya yang sudah tertanam dalam masyarakat dan mengembangkannya dalam bentuk yang lebih baik (Marsono, 2019).

\section{METODE PENELITIAN}

Pada penelitian ini penulis menggunakan metode penelitian deskriptif yaitu dengan mengumpulkan data-data bersifat kepustakaan yang relevan dengan masalah yang sedang diteliti. Kepustakaan yang bersumber dari buku, jurnal ilmiah yang berupa artikel, skripsi, dan sumber lainnya berdasarkan peneliti atau para ahli terdahulu. Metode ini dilakukan dengan membaca berbagai sumber yang kemudian dihubungkan dengan topik yang diteliti atau dibahas untuk kemudian disampaikan dalam bentuk deskripsi.

\section{HASIL PENELITIAN DAN PEMBAHASAN}

Perkembangan teknologi merupakan sebuah hasil dari berkembangnya ilmu pengetahuan yang terjadi dalam dunia pendidikan dari masa ke masa. Perkembangan teknologi ini membawa perubahan yang sangat besar dalam tatanan kehidupan. Sangat banyak dampak negatif dan dampak positif dari adanya perkembangan teknologi ini.

Herlambang (2018) menyatakan dampak negatif dan dampak positif dari perkembangan teknologi. Dampak positif perkembangan teknologi, antara lain:

1. Membuat masyarakat mudah dalam mencari informasi yang dibutuhkan

2. Membuat masyarakat mudah dalam berinteraksi secara global

3. Membuat masyarakat mudah dalam menciptakan atau membuka lapangan pekerjaan juga membuat masyarakat mudah dalam mengembangkan jiwa kewirausahaan

4. Membuat masyarakat mudah dalam mengerjakan dan menyelesaikan tugas sehari-hari dengan dibantu oleh teknologi yang selalu berkembang

Sedangkan dampak negatif dari perkembangan teknologi, sebagai berikut:

1. Mereduksi nilai-nilai budaya

2. Membuat masyarakat bermental instan atau segalanya serba ingin cepat

3. Membuat kejahatan di dunia maya semakin banyak 
P-ISSN $2580-7781$

E-ISSN 2615 - 3238

4. Dekadensasi moral atau kemerosotan akhlak

5. Hilangnya realita kehidupan sosial dan terbentuknya sifat malas

6. Mentalitas teknologi atau teknosentris artinya sikap percaya berlebih pada suatu alat

Dampak dari perkembangan teknologi yang paling sering ditemukan yaitu mereduksi nilai-nilai budaya atau lunturnya nilai-nilai budaya, dimana itu terjadi karena individu tersebut terlalu fokus pada perkembangan teknologi yang ada dan mudah terpengaruh oleh berbagai isu global sehingga individu tersebut dapat melupakan atau meninggalkan nilai-nilai budaya yang sebelumnya telah tertanam di masyarakat.

Kebudayaan adalah suatu hasil karya manusia yang bisa mengembangkan sikap sekelompok masyarakat terhadap kehidupan yang kemudian diwariskan pada generasi selanjutnya melalui proses komunikasi dan belajar agar generasi tersebut memiliki karakter yang kuat dalam kehidupan (Yunus, 2013). Nilai-nilai budaya biasanya memuat suatu kebiasaan, kepercayaan, karakteristik yang telah lama tertanam pada masyarakat tertentu. Dengan adanya perkembangan teknologi, nilai-nilai budaya yang dimiliki oleh bangsa Indonesia belum terimplementasi dengan optimal atau bahkan menurun seperti menurunnya perilaku jujur, sopan santun, rasa gotong royong, rasa kebersamaan diantara anggota masyarakat.

Pendidikan juga diartikan sebagai suatu usaha yang dilakukan secara sadar dan sistematis agar tercipta tatanan hidup dan kemajuan ke arah lebih baik. Menurut Kristiawan (Ngongo et al, 2019), berbagai jenis kegiatan yang terdapat dalam proses pendidikan seperti penanaman nilai, pengembangan budi pekerti, nilai keagamaan, pembelajaran dan juga pelatihan nilai-nilai moral, dan sebagainya dapat mewujudkan atau membentuk karakter.

Pendidikan harus bisa mengikuti perkembangan teknologi dan juga harus bisa membawa nilai-nilai budaya dalam setiap perkembangannya. Teknopedagogik merupakan sebuah paradigma baru pendidikan dalam kehidupan di era digital ini. Teknopedagogik lahir untuk memajukan pendidikan pada era digital ini dan meminimalisir dampak negatif dari perkembangan teknologi. 
P-ISSN $2580-7781$

E-ISSN 2615 - 3238

Dalam teknopedagogik guru atau tenaga pendidik dituntut untuk literatur dalam perkembangan teknologi (Herlambang, 2018).

Perkembangan teknologi membuat informasi atau isu global masuk dengan mudah, dan informasi tersebut dapat diakses kapan dan dimana saja. Sehingga apabila pendidikan tidak memerankan perannya dalam mendidik anak untuk literasi digital dan menanamkan nilai-nilai budaya yang telah ada, maka masyarakat akan mudah terpengaruh oleh berbagai informasi atau isu yang ada tanpa adanya proses filterisasi.

Dengan adanya pendidikan berbasis budaya, diharapkan dapat membuat individu atau masyarakat mengenal identitas budayanya sendiri, dan mampu membedakan informasi atau isu global mana yang baik untuk diterima juga mana yang tidak baik untuk diterima atau melakukan filterisasi. Jika masyarakat telah mampu melakukan filterisasi kebudayaan maka akan membantu pengembangan kebudayaan kedepannya. Beberapa tahap yang harus dilalui dalam pengembangan kebudayaan, yaitu mulai dari sadar akan jati diri, memfilter budaya asing, juga asimilasi atau akulturasi (Marsono, 2019).

Dalam pengembangan kebudayaan maka hal yang paling pertama dilakukan adalah menanamkan kesadaran dan memperkokoh jati diri atau identitas bangsa pada setiap individu. Penanaman kesadaran jati diri atau identitas bangsa pada setiap individu dapat dilakukan melalui pendidikan, salah satunya Pendidikan Kewarganegaraan, karena jati diri bangsa atau identitas bangsa Indonesia diantaranya adalah bahasa Indonesia sebagai bahasa persatuan, bendera merah putih, lagu Indonesia Raya sebagai lagu kebangsaan, Pancasila sebagai lambang negara, Bhinneka Tunggal Ika sebagai semboyan negara, Pancasila sebagai dasar falsafah negara, dan yang lainnya. Makna yang terkandung dalam identitas bangsa harus dapat terimplementasikan dengan baik pada masyarakat agar nilainilai kebudayaan Indonesia tidak mudah terkikis oleh isu global dari perkembangan teknologi.

Setelah nilai-nilai budaya tertanam kokoh pada setiap masyarakat Indonesia maka, maka upaya selanjutnya adalah menanamkan standar teknologi untuk murid dan guru yang dikemukakan International Society for Technology in Education 
P-ISSN $2580-7781$

E-ISSN 2615 - 3238

(ISTE) (Susan Brooks-Young dalam Herlambang, 2018) bahwa ada enam standar teknologi untuk murid dan guru, yaitu:

1. Creativity and innovation: mampu berpikir kreatif, membangun pengetahuan, juga mengembangkan produk inovasi dengan teknologi.

2. Communication and collaboration: bekerja secara kolaboratif juga meningkatkan pembelajaran jarak jauh (PJJ) menggunakan media dan konteks digital.

3. Research and information fluency: mengumpulkan informasi, mengevaluasi informasi dan juga menggunakan informasi melalui aplikasi alat digital.

4. Critical thinking, problem solving, and decision making: mampu berpikir kritis dalam mempersiapkan atau merencanakan penelitian, pengelolaan proyek, menyelesaikan masalah, juga dalam membuat keputusan yang baik dengan menggunakan teknologi yang sesuai.

5. Digital citizenship: melakukan upaya dalam meningkatkan pemahaman mengenai isu-isu yang beredar seperti isu komunitas, manusia, dan budaya yang terkait teknologi dan mampu untuk menunjukkan perilaku etis.

6. Technology operation and concept: memahami betul operasi dan juga konsepkonsep teknologi.

Penanaman nilai-nilai budaya dan literasi teknologi telah dilakukan, selanjutnya yang berperan untuk mengimplementasikan dan mempertahankan itu semua adalah masyarakat. Masyarakat memiliki peran dan pengaruh yang kuat dalam segala hal. Maka diperlukan masyarakat yang berkualitas untuk dapat mengupayakan agar perkembangan teknologi tidak mereduksi nilai-nilai budaya.

\section{KESIMPULAN}

Perkembangan teknologi merupakan bukti dari kemajuan ilmu pengetahuan. Perkembangan teknologi sangat berpengaruh pada setiap tatanan kehidupan dan mempunyai dampak positif juga dampak negatif salah satunya adalah dapat mereduksi nilai-nilai kebudayaan. Maka diperlukan penanaman nilai-nilai budaya pada masyarakat dan literasi teknologi agar dapat melakukan filterisasi informasi dan juga tidak mudah terpengaruh terhadap isu global, serta dapat meminimalisir dampak negatif dari perkembangan teknologi tersebut. Diperlukan juga peran 
P-ISSN $2580-7781$

E-ISSN $2615-3238$

masyarakat untuk mengimplementasikan nilai-nilai yang sudah tertanam agar terus berkembang menuju arah yang lebih baik. Karena masyarakat, pendidikan, dan kebudayaan merupakan suatu sistem yang saling berkaitan dan tidak dapat dipisahkan baik di era digital maupun di era sebelumnya.

\section{DAFTAR PUSTAKA}

Herlambang, Y. T. (2018). Pedagogik: Telaah Kritis Ilmu Pendidikan dalam Multiperspektif.

Lase, D. (2019). Pendidikan di Era Revolusi Industri 4.0. Jurnal Sundermann, 12(2), 28-43.

Latra, I. W. (2017). Identitas Nasional Sebagai Salah Satu Determinan Dalam Pembangunan Bangsa Dan Karakter. Https://Simdos.Unud.Ac.Id/ Uploads/File_Penelitian_1_Dir/73897666Bed07Ff50B5B2Bf1Ed73E60. Pdf, 1-18.

Lestari, S. (2018). Peran Teknologi Dalam Pendidikan di Era Globalisasi. Edureligia: Jurnal Pendidikan Agama Islam, 2(2), 94-100.

Marsono. (2019). Pendidikan Karakter Berbasis Nilai Budaya Di Era Milenial. Tantangan Dan Peluang Dunia Pendidikan Di Era 4.0, 51-58.

Nasution, R. D. (2017). Effect of the Development of Communication Information Technology on Local Cultural Existence. Jurnal Penelitian Komunikasi Dan Opini Publik, 21(1), 30-42.

Ngongo, V. L., Hidayat, T., \& Wijayanto. (2019). Pendidikan di Era Digital. Prosiding Seminar Nasional Pendidikan Program Pasca Sarjana Universitas PGRI Palembang, 628-638.

Yunus, R. (2013). Transformasi Nilai-Nilai Budaya Lokal Sebagai Upaya Pembangunan Karakter Bangsa (Penelitian Studi Kasus Budaya Huyula Di Kota Gorontalo). Jurnal Penelitian Pendidikan, 14(1), 65-77. 